\title{
Managerial Competencies for Various Management Levels
}

\begin{abstract}
In the light of the role they play in the effective management of organisations, managerial competencies are a subject of interest for researchers throughout the world today. This is reflected in the huge number of publications on the topic. The competencies of managers of both enterprises and public organisations are investigated.

The managerial competency list is a basic managerial competencies management tool that enables the identification, realisation assessment and development of necessary managerial competencies. The list can be used to identify competency gaps among management staff.

The objective of the article is to list managerial competencies the author believes are necessary for managers in contemporary enterprises, based on a review of the literature. The results of the research indicate significant competencies for the effective performance of managers at various levels of management: highest, middle, lowest. Delphi method was used in the research, in which the following participated: 100 experts, including 42 professors of management and 58 managers from various levels of management in the enterprises employing at least 50 employees. The results of the research were compared with the R. L. Katz's model of managerial skills.
\end{abstract}

Keywords: managerial competencies, the Delphi method, the significance of managerial competencies, R. L. Katz's model of managerial skills.

JEL Classification: M5.

Małgorzata Tyrańska, Cracow University of Economics, Faculty of Management, Department of Management Process, 31-510 Kraków, Rakowicka 27, e-mail: tyranskm@uek.krakow.pl 


\section{Introduction}

Managerial competencies are today a subject of research throughout the world, a fact reflected by the huge number of publications on the topic. The competencies of enterprise and public organisation managers are investigated. This great interest can be attributed to the role managerial competencies play in the effective management of organisations. Several empirical studies have established the relationship between managerial competencies and job performance (Huping \& Wenxuan 2013, pp. 1469-1486; Jena \& Sahoo 2014, pp. 143-149; Bamel et al., 2015, pp. 202-225; Lakshminarayanan, Pai \& Ramaprasad 2016, pp. 423-430).

According to Lakshminarayanan, Pai, and Ramaprasad, competencies are characteristics that enable one to perform his or her job. They consist of numerous forms and combinations of knowledge, skills, abilities, motives and traits (2016, p. 423). Competencies are qualities the individual can use to perform activities in an exemplary and successful manner (Dubois \& Rothwell 2008, p. 26). Oleksyn indicates the main aims of mangerial competencies are to ensure indispensable competencies that - mainly people, the organisation and finally the entire society - guarantee high quality work and life; to help individuals become highly effective and competitive; to develop people's abilities to perform professional work as it allows them to achieve self-fulfilment, support their families and have dignity in each field of their lives; to adjust competencies to changing needs, which requires the individual to improve his or her qualifications. Some will require retraining, a change of workplace or organisational rules and indispensable flexibility (2006, p. 40). Masłyk-Musiał specifies that the aim of managerial competencies in the enterprise is to determine which of them are demanded in the post of manager and to prevent the loss of competencies (2005, p. 11).

The list of managerial competencies is a basic enterprise tool in managerial competencies management: It identifies, assures, assesses and develops necessary managerial competencies. The list is a set of generally or specifically defined competencies required at a given managerial position (Walkowiak 2004, p. 34). Generally defined lists include core competencies, while specifically defined ones cover special competencies. The lists of competencies can contain competencies ordered generically - that is, a set of technical, social or conceptual competencies, or they can constitute a casual, disordered set of competencies. Competencies composing a particular list may be arranged hierarchically - from most to least important - or according to the efficiency criterion of managerial activities. 
The objective of the article is to provide the list of managerial competencies which I believe are necessary for managers managing contemporary enterprises, based on a review of the literature. The research question addressed was: which competencies are crucial to make management activities efficient and effective at all levels of management: high, middle and low. Delphi method was used and the following participated: 100 experts, including 42 professors of management and 58 managers from various levels of management in enterprises employing at least 50 employees. The results of the research were compared with the R. L. Katz's model of managerial skills. The list of competences developed on the basis of the research can be applied to identify competency gaps among management.

\section{A Typology of Managerial Competencies}

Many authors emphasise the need to divide managerial competencies into categories, groups or types. The lists of managerial competencies proposed by a number of authors are presented below.

Pocztowski sets out the following managerial competencies (2003, p. 155):

- threshold competencies - essential for the proper performance of a certain job, such as knowledge and skills, and in the case of a manager professional knowledge, problem solving, communicating, forming relationships and using consultants;

- differentiating competencies - competencies differentiating an effective employee from others. These include attitudes, motives and values. In the case of managers, the list extends to leadership, empathy, willingness to learn, tolerance for ambiguity, a focus on creativity, orientation on the future and awareness of value.

Filipowicz lists the following as managerial competencies: team building, taking care of subordinates, delegating, motivating, managerial courage, leadership, organising, planning, process management, project management, strategic thinking, change management (2004, pp. 37-38).

Huping and Wenxuan indicate twenty-four managerial competencies: understanding self and others, communicating effectively, developing employees, building teams, using participative decision-making, managing conflicts, managing info/critical thinking, managing information overload, managing core processes, managing projects, designing work, managing across functions, developing/communicating vision, setting goals and objectives, designing and organising, working productively, fostering a productive work environment, managing time/stress, living with change, thinking creatively, managing change, building/ maintaining one's power base, negotiating agreement/commitment, presenting ideas (2013, pp. 1474-1476). 
Lakshminarayanan, Pai and Ramaprasad distinguish six main competency categories: analytic skills, self-management, relationship management, selfawareness, goal and action management, social awareness (2016, pp. 423-430). Within each category they highlight several specific competencies (Table 1).

Table 1. Lakshminarayanan, Pai and Ramaprasad's Structure of Managerial Competencies

\begin{tabular}{|c|c|c|}
\hline Analytic Skills & Self-management & Relationship Management \\
\hline $\begin{array}{l}\text { 1. Appropriate use of concepts } \\
\text { 2. Systems thinking } \\
\text { 3. Recognising patterns in } \\
\text { assorted data } \\
\text { 4. Building theory for process } \\
\text { improvement and trouble- } \\
\text {-shooting } \\
\text { 5. Using advanced technolo- } \\
\text { gies } \\
\text { 6. Analysing data quantita- } \\
\text { tively } \\
\text { 7. Social objectivity } \\
\text { 8. Clearly communicating } \\
\text { important aspects of tasks } \\
\text { and responsibilities }\end{array}$ & $\begin{array}{l}\text { 1. Demonstrate self-control } \\
\text { 2. Behaviour driven by } \\
\text { achievement and motivation } \\
\text { 3. Display adaptability in } \\
\text { a dynamic work environ- } \\
\text { ment } \\
\text { 4. Showcase transparency in } \\
\text { all work-related issues } \\
\text { 5. Taking initiative } \\
\text { 6. Evince optimism in all } \\
\text { situations }\end{array}$ & $\begin{array}{l}\text { 1. Lead by example } \\
\text { 2. Positively influence and } \\
\text { motivate co-workers } \\
\text { 3. Effectively manage con- } \\
\text { flicts } \\
\text { 4. Be a catalyst to change } \\
\text { 5. Develop others } \\
\text { 6. Promote teamwork and } \\
\text { collaboration }\end{array}$ \\
\hline Self-awareness & Goal and Action Management & Social Awareness \\
\hline $\begin{array}{l}\text { 1. Strive to understand oneself } \\
\text { 2. Accurately assessing the } \\
\text { self } \\
\text { 3. Exhibit self-confidence in } \\
\text { all situations }\end{array}$ & $\begin{array}{l}\text { 1. Plan each task meticulously } \\
\text { 2. Continously strive to } \\
\text { achieve efficiency } \\
\text { 3. Pay attention to minutest } \\
\text { details } \\
\text { 4. Exhibit flexibility with } \\
\text { regards to process and } \\
\text { solutions }\end{array}$ & $\begin{array}{l}\text { 1. Show empathy } \\
\text { 2. Display continuous orienta- } \\
\text { tion towards service } \\
\text { 3. Be aware of organisation's } \\
\text { processes, policies and rules }\end{array}$ \\
\hline
\end{tabular}

Source: the author's own elaboration, based on (Lakshminarayanan, Pai \& Ramaprasad 2016, pp. 423-430).

I used Lakshminarayanan, Pai and Ramaprasad's list of competencies in identifying competency gaps among 106 managers from 18 enterprises. The results of the research showed that the largest gaps were found in four dimensions: analytic skills, self-management, relationship management and goal and action management. These competency gaps are especially associated with competencies including the ability to analyse data quantitatively, display adaptability, positively influence and motivate co-workers, and change management, planning and execution to attract maximum importance. This is consistent with 
previous studies which have expounded the importance of such competency dimensions in improving overall managerial effectiveness and performance (Jena \& Sahoo 2014, pp. 143-149).

Oleksyn states that the expected competencies of managers at various levels of management overlap, but in some aspects are different. Therefore, the specificity of requirements concerning different levels of management should be considered. After all, what is important for a chairman of the board or CEO is usually not for lower level managers, and vice versa. Therefore, it makes no sense to describe them in a universal and unified manner. However, efficient performance and the ability to achieve the designated targets is required of every manager (Oleksyn 2006, p. 158).

The highest level of management includes a relatively small group of people that control the organisation and bear responsibility for all its operations. In the classical approach, the organisational positions of managers managing the enterprise on behalf of the owner constitute the highest level of management. The manager of top management takes strategic decisions and determines the development of the enterprise in the long term. The decisions made at this level are associated with the effective use of the organisation's resources.

Table 2. High-level Management Competencies

\begin{tabular}{|c|c|c|}
\hline $\begin{array}{c}\text { Knowledge and Skills in Area } \\
\text { of Strategic Management }\end{array}$ & Personal Competencies & Social Competencies \\
\hline $\begin{array}{l}\text { - knowledge of the various } \\
\text { types of strategy } \\
\text { - ability to give proper } \\
\text { direction for the enterprise's } \\
\text { development } \\
\text { - ability to make decisions of } \\
\text { key importance relating to } \\
\text { mergers and acquisitions, } \\
\text { restructuring, outsourcing, } \\
\text { purchase or sale of shares } \\
\text { - proceed in accordance with } \\
\text { the principles of business } \\
\text { ethics } \\
\text { - imagination and the ability } \\
\text { to anticipate } \\
\text { - oriented on system manage- } \\
\text { ment } \\
\text { - ability to generate profits }\end{array}$ & $\begin{array}{l}\text { - responsibility } \\
\text { - reliability } \\
\text { - kindness } \\
\text { - magnanimity } \\
\text { - self-criticism and modesty } \\
\text { - communication skills } \\
\text { - ease of establishing contacts }\end{array}$ & $\begin{array}{l}\text { - ability to recognise com- } \\
\text { mon interests on organisa- } \\
\text { tional scale } \\
\text { - empathy } \\
\text { - ability to cooperate with } \\
\text { people and have an effective } \\
\text { influence on them } \\
\text { - serving its interests and } \\
\text { dignified representing the } \\
\text { organisation outside } \\
\text { - ability to choose people } \\
\text { for key positions in the } \\
\text { organisation }\end{array}$ \\
\hline
\end{tabular}

Source: the author's own elaboration, based on (Oleksyn 2006, pp. 158-162). 
The manager of the highest level of management performs the role of strategist. Therefore, he should have competencies conducive to shaping the future, and appropriate personal and social competencies (Table 2). As the organisation's strategist, the top manager has a big impact on forming the organisation's mission and vision, its domain of action, strategic objectives and developmental strategies. While shaping these elements of management, he or she does not deal with this individually, but works with the owners of the enterprise, strategic management experts, the most important line managers, heads of independent business units, and employee representatives. Future-looking competencies allow the manager to prepare the organisation to function effectively and efficiently in the future, survive and develop, maximise long-run profits, fulfill the company's social mission, and protect it against internal and external threats.

Mid-level management is made up of the heads of organisational units who serve advisory functions towards the highest level of management, and simultaneously bear the responsibility for the organisational unit (department, division) and the range of issues associated with it. These managers determine strategy at a functional level and make tactical decisions related to the organisation as a whole on the technical, financial, organisational and human resources side of the business. The decisions they make concern medium and close time horizons. The tactical decisions translate the general objectives set out at the highest level of management into a technique and task methodology, which is implemented at lower level of management.

Table 3. Middle Management Competencies

\begin{tabular}{|l|l|}
\hline \multicolumn{1}{|c|}{ Interpersonal Competencies } & \multicolumn{1}{c|}{ Innovative Competencies } \\
\hline - ability to choose appropriate people and & $\begin{array}{l}\text { - ability to anticipate changes and have posi- } \\
\text { build teams }\end{array}$ \\
- integrating, inspiring and motivating & - determination in action \\
employees & - ability to connect overall vision with atten- \\
- $\begin{array}{l}\text { assensment of work and employees } \\
\text { - professional development }\end{array}$ & - participatory leadership style \\
- communication, negotiation and conflict & - perseverence combined with ability to per- \\
resolution & suade and tact \\
ability to act as a liaison officer between the & - ability to carefully observe the introduced \\
chief executive officer and other people in & changes \\
a given area and represent them & \\
\hline
\end{tabular}

Source: the author's own elaboration, based on (Oleksyn 2006, pp. 163-165).

The mid-level manager acts as an integrator whose task is to organise horizontal cooperation with equivalent organisational units, external institutions and coordinate work within the organisational unit (Table 3). Strategic management 
and preparing a part of the organisation to function smoothly in the future are essential to his work. He or she has professional qualifications and is a specialist in an industry, being, most commonly, an engineer, economist, lawyer, psychologist or management specialist. A mid-level manager is expected to have interpersonal and innovative skills.

The first line of management is made up of of heads of organisational units who work directly with those who do the work. Organisational unit managers (departments or sections) belong to this group. Executive actions dominate the work of this managerial group (Table 4). Self-reliance is limited to the allocation of tasks and means of its implementation, and responsibilities include cooperation with others and implementing tasks. The manager of the first line of management makes operational decisions concerning the realisation of tasks commissioned by the supervisor. A direct relationship between the issuer of decisions and the employee-contractor exists at this level of management. These decisions are short-term, based on a particular day's work and related to the rational use of labour resources. They are also made during the implementation of current tasks according to the daily schedule of activities.

Table 4. Low-level Management Competencies

\begin{tabular}{|l|l|}
\hline \multicolumn{1}{|c|}{ Managerial Predispositions } & \multicolumn{1}{c|}{$\begin{array}{c}\text { Substantive Knowledge in the Field } \\
\text { of Management }\end{array}$} \\
\hline $\begin{array}{l}\text { - effective coordination of activities } \\
\text { - consideration } \\
- \text { justice }\end{array}$ & $\begin{array}{l}\text { - knowledge of marketing management } \\
- \text { knowledge of basic organisation } \\
\text { comprehensibility }\end{array}$ \\
& $\begin{array}{l}\text { management } \\
- \text { knowledge of HR management }\end{array}$ \\
\hline
\end{tabular}

Source: the author's own elaboration, based on (Oleksyn 2006, pp. 165-166).

The list of managerial competencies constitutes a frame of reference enabling the competencies of a particular manager to be compared. As a result, it can be used to assess the actual managerial competencies possessed, determine the competence gap and indicate the reasons for its occurrence. The permanent assessment of managerial competencies makes it possible to help managers modify their behaviour, indicate the directions of their individual development, and adjust the competencies to current and future core competencies of the enterprise.

The creation of lists of competencies has also come in for criticism in the literature. These include the following: Even if managers have all of the competencies from the list, there is no guarantee that they will work effectively; when creating the list of competencies, it is assumed that there is only one "set of 
competencies" which leads to good results, but the other "sets" may also lead to their achievement; none of the lists are complete and when creating them, the organisational or cultural context, which allows a better understanding of managerial work, is not always taken into account (Rakowska 2005, p. 99).

These limitations can be addressed by allowing for the following variables that differentiate the competencies model: management level, function performed by the manager in the enterprise, branch in which a particular enterprise operates and its strategic goals. The enterprise's organisational culture, which approves or disapproves of specific type of behaviours, should also be taken into consideration when the competence model is created (Pocztowski \& Miś 2000, p. 72).

Thus when creating the list of competencies, the manager should take into account the specificity of the work, the scope of decision-making powers, the complexity of the work used and information created and the diversity of the relationships related to the level of management at which a particular managerial position can be found, as well as the roles played by managers holding positions at different levels of management in the enterprise.

\section{Research Assumptions}

The list of competencies was proposed on the basis of the achievements of other researchers. Under that list of competencies, universal competencies and competencies specific to managerial positions were distinguished. The universal competencies directly result from key organisational competencies and support the implementation of the enterprise's mission, vision and strategy. These competencies were divided into three groups (see Tyrańska 2015, p. 109):

1) general competencies: substantive, professional maturity, responsibility for decision making, ethics, informatics and knowledge of foreign languages;

2) leadership: teamwork, coaching, negotiating, motivating subordinates and communicating;

3) business: strategic and analytical thinking, implementing changes, innovation, project management and biased results.

The specialised competencies include appropriate competencies to the functional area to which the managerial position belongs. Having specialised competencies at the highest level presupposes that managers become experts in their field of employment (see Tyrańska 2015, p. 109):

For managers responsible for marketing management, specialised competencies include creativity in selecting instruments for marketing activities, and knowledge about: factors influencing the situation on the market, market analysis tools and insights on customer needs, methods of psychological influence on 
the attitudes of customers, and the ability to build a marketing strategy, create a relationship with customers and business partners, build a reputation and brand image, create advertising briefs and media plans, apply market communication techniques and sales techniques, and evaluate decisions in economic terms.

For managers responsible for operational management, specialised competencies include knowledge of the following: production engineering in the industry in which the enterprise operates, advanced methods of production management (such as lean manufacturing, Kanban, JiT and MRP), cost accounting, expert systems to support production, knowledge of TQM, and the ability to supervise and control technological processes, create optimal logistics chains, organise individual and teamwork, evaluate decisions in economic terms.

For HR managers, specialised competencies include knowledge of the following: current labour law and insurance regulations, employee developmental competencies methods, results management and the ability to evaluate decisions in economic terms, and knowledge and experience in the recruitment and assessment of employees.

For finance managers, specialised competencies encompass formal qualifications such as ACCA (Association of Chartered Certified Accountants), CIMA (Chartered Institute of Management Accountants), and knowledge of the following: tax law and regulations governing corporate reporting, managerial and financial accounting, financial and capital markets, the factors influencing the value of the enterprise, ERP systems including SAP, and the ability to do the following: acquire and evaluate different sources of working and investment capital, technological and economic forecasting and planning and conducting economic and financial analysis, use controlling, anticipate the financial consequences of business operations and make quick decisions.

Such a division of competencies increased the transparency of the list and made it possible to examine the relevance of selected groups of competencies for all three management groups.

The Delphi method was used to determine the importance of the groups of competencies for achieving the effectiveness of managers at every level of management. The Delphi method was developed and applied by Olaf Helmer in 1963 in connection with research at the RAND Corporation (Research and Development Corporation). The idea of this approach is to formulate predictions based on the opinions of independent experts. The method is based on a qualitative assessment of facts, on intuition, and on the individual associative scheme of researchers, a knowledge and prediction algorithm. This knowledge is based on flexible inquiry and the admission in reasoning of an assumption of subjective probability of certain events occurring and a causal relationship between them (Gierszewska \& Romanowska 1999, pp. 52-54; Stabryła 2011, pp. 144-145). 
The experts' opinions were analysed statistically. On the basis of a synthetic assessment, the results of significance of competencies established scales for groups of competencies at various levels of management, according to these formulas:

$$
\begin{gathered}
w_{i}=\sum_{j=1}^{n} w_{i j} \\
\bar{w}_{i}=\frac{w_{i}}{n}
\end{gathered}
$$

where:

$w_{i}$ is the total scale for $i$-th competence, where $i=1, \ldots, m$,

$w_{i j}$ is the scale given to $i$-th competence because of $j$-th assessment criteria, where $j=1, \ldots, n$,

$\bar{w}_{i}$ is the average scale of $i$-th competence,

$n$ is the number of assessment criteria.

The higher the scale of the group of competencies, the greater their importance for the effectiveness of managers at a given level of management.

\section{Results}

The research was conducted from November 2012 to October 2013. Researchers and managers were invited to fill out questionnaires, which were sent by e-mail. 100 experts responded, including 42 researchers, mainly management specialists from 13 research centres in Poland, and 58 managers of manufacturing, trading and servicing enterprises, largely located in southern Poland. The vast majority of researchers were professors (45\%), associate professors $(17 \%)$, assistant professors (36\%) and employees with a $\mathrm{PhD}$ degree (2\%). Among the practitioners were found high level managers (44\% of all respondents-practitioners), middle managers (34\%) and low-level managers (22\%) of enterprises employing at least 50 employees.

Using their theoretical knowledge and practical experience, the experts assessed the significance of selected groups of managerial competencies from the point of view of their impact on the effectiveness of managers employed at the three levels of management. A 1 to 5 scale was used, with 1 standing for neutral competencies for the implementation of the manager's tasks at a given level of management, and 5 being dominant competencies, and thus having the greatest impact on the effectiveness of the manager. 
In order to generalise the experts' opinions, $44 \%$ of all respondents-practitioners, scales for selected groups of competencies at the various management levels were established. For this purpose, formulas 1 and 2 were used. Subsequently, the share of the average scales of experts in the overall assessment of competency validity at a given level of management were determined. The higher percentage of scale for a given group of competencies, the greater its impact on the effectiveness of the manager at a given management level. Results of this part of the research are shown in Table 5.

Table 5. Share Structure of Groups of Competencies in the Overall Assessment of Their Validity

\begin{tabular}{|l|c|c|c|c|c|c|c|c|c|}
\hline \multirow{2}{*}{$\begin{array}{c}\text { Managerial } \\
\text { competencies }\end{array}$} & \multicolumn{3}{|c|}{$\begin{array}{c}\text { According to Professors } \\
(n=42)\end{array}$} & \multicolumn{3}{c|}{$\begin{array}{c}\text { According to Managers } \\
(n=58)\end{array}$} & \multicolumn{3}{c|}{$\begin{array}{c}\text { According to all Experts } \\
(n=100)\end{array}$} \\
\cline { 2 - 11 } & $\begin{array}{c}\text { Highest } \\
\text { level }\end{array}$ & $\begin{array}{c}\text { Middle } \\
\text { level }\end{array}$ & $\begin{array}{c}\text { Lowest } \\
\text { level }\end{array}$ & $\begin{array}{c}\text { Highest } \\
\text { level }\end{array}$ & $\begin{array}{c}\text { Middle } \\
\text { level }\end{array}$ & $\begin{array}{c}\text { Lowest } \\
\text { level }\end{array}$ & $\begin{array}{c}\text { Highest } \\
\text { level }\end{array}$ & $\begin{array}{c}\text { Middle } \\
\text { level }\end{array}$ & $\begin{array}{c}\text { Lowest } \\
\text { level }\end{array}$ \\
\hline General & 0.26 & 0.24 & 0.25 & 0.26 & 0.25 & 0.25 & 0.26 & 0.24 & 0.25 \\
\hline Leadership & 0.26 & 0.26 & 0.26 & 0.26 & 0.26 & 0.27 & 0.26 & 0.26 & 0.26 \\
\hline Business & 0.29 & 0.24 & 0.19 & 0.28 & 0.24 & 0.20 & 0.28 & 0.24 & 0.20 \\
\hline Specialised & 0.19 & 0.26 & 0.30 & 0.20 & 0.25 & 0.28 & 0.20 & 0.26 & 0.29 \\
\hline Total & 1.00 & 1.00 & 1.00 & 1.00 & 1.00 & 1.00 & 1.00 & 1.00 & 1.00 \\
\hline
\end{tabular}

Source: (Tyrańska 2015, p. 136).

At the highest level of management, business competencies are the most important, perhaps because managers at this level have the greatest impact through decision-making on the financial results of the enterprise. The professors recognised business competencies as slightly more important than the managers did. At the same level, the experts determined the validity of general and leadership competencies. By contrast, experts recognised specialised competencies as the least important for the effectiveness of a manager's work at this level of management. The managers felt it was slightly more important to have the relevant competencies to function effectively as a manager at the highest level of management.

For middle managers the experts believed that leadership and specialised competencies were the most important, followed by general and business competencies. In particular, the managers attributed slightly greater importance to general competencies, while the professors assessed specialised competencies as slightly more important than the managers did. According to the experts, middle- 
-level managers should be first and foremost effective leaders, enjoy respect, have a strong influence on the behaviour of subordinates, know how to stimulate them to act, and also be very good specialists in the area they manage.

According to the experts, the hierarchy of competencies for low-level managers is the following: specialised competencies, followed by leadership, general and business competencies. Business competencies were the least important at this level, as results of decision-making at this level have a negligible impact on financial results. All experts were unanimous in assessing the relevance of general competencies for low-level managers. There were minor differences in the assessments of professors and managers for other groups of competencies. For example, professors assessed the specialised competencies higher, while the managers assessed business and leadership competencies slightly higher than the professors did. In the experts' opinions, the manager at the lowest level of management is primarily a very good specialist in the area he or she manages.

\section{The Importance of Managerial Competencies According to R. L. Katz's Model and My Own Research Results}

To sum up the research conducted, the experts' opinions are convergent with Katz's 1955 model of the distribution of managerial skills (Katz 1974, pp. 94-96; Peterson \& Van Fleet 2004, p. 1299). The following assumptions make the two models comparable: knowledge and professional experience create general competencies that are a condition for the development of other distinguished competencies; conceptual skills are the basis for business competencies; interpersonal skills are essential for having leadership competencies; and technical skills are the basis for specialised competencies. The two models are very similar in their assessment of the highest and the lowest level of management while slight differences emerged at the middle level (Figure 1).

As in Katz's model, the experts attributed the greatest importance to business competencies for high-level management, which constitutes the basis for conceptual skills identified as essential in the comparable model. According to Katz, conceptual skills and the manager's ability to use subordinates' technical skills are important for middle managers - more important than their own technical efficiency. Experts assessing the hierarchy of competencies at this level of management concluded that leadership competencies are the most important because the manager will be able to efficiently manage subordinates.

Finally, Katz found that the lowest level of management is dominated by technical skills, and the role of conceptual skills is neglibile. My research found the 
same to be true. At the lowest level of management, specialised competencies gain importance, and constitute the basis for technical skills.

For both R. L. Katz and other experts, interpersonal skills are equally important for managers at all levels. In my research, experts indicated that general competencies at all levels of management were second most important. This finding is also similar to Katz's model, both of which lead to the conclusion that knowledge and professional experience form the basis of all managerial skills. In addition to these, the ability to make decisions, understand and use foreign languages, use professional ethics and technological skills round out the general competencies in the proposed model.

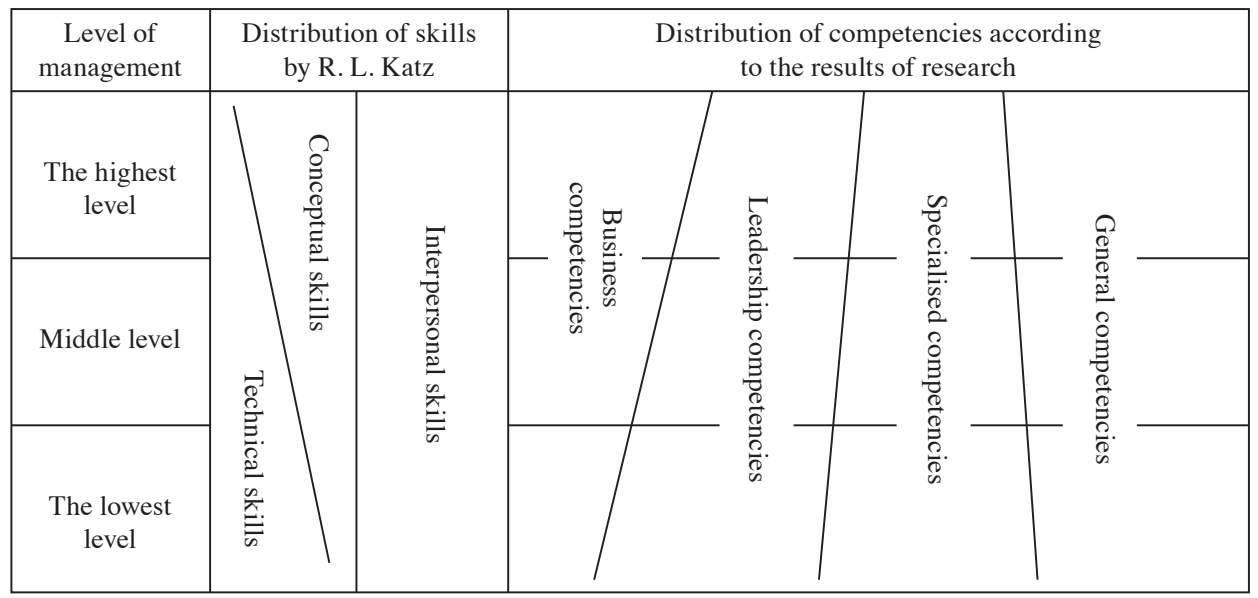

Fig. 1. The Significance of Managerial Competencies at Different Levels of Management (R. L. Katz's Model and Own Research Results)

Source: the author's elaboration based on own research results and (Katz 1974, pp. 94-96; Listwan 1993, p. 13).

The analysis of 100 experts' opinions of the theory and practice of management has led to the determination of a hierarchy of importance of managerial competencies at various management levels. At the highest level of management, key competencies are business competencies while for middle managers the most important competency is leadership, and for low-level managers specialised competencies are of the greatest importance.

According to the experts, IT competencies, knowledge of foreign languages and ethical competencies are gaining particular importance and are the most important general competencies (Figure 2). 


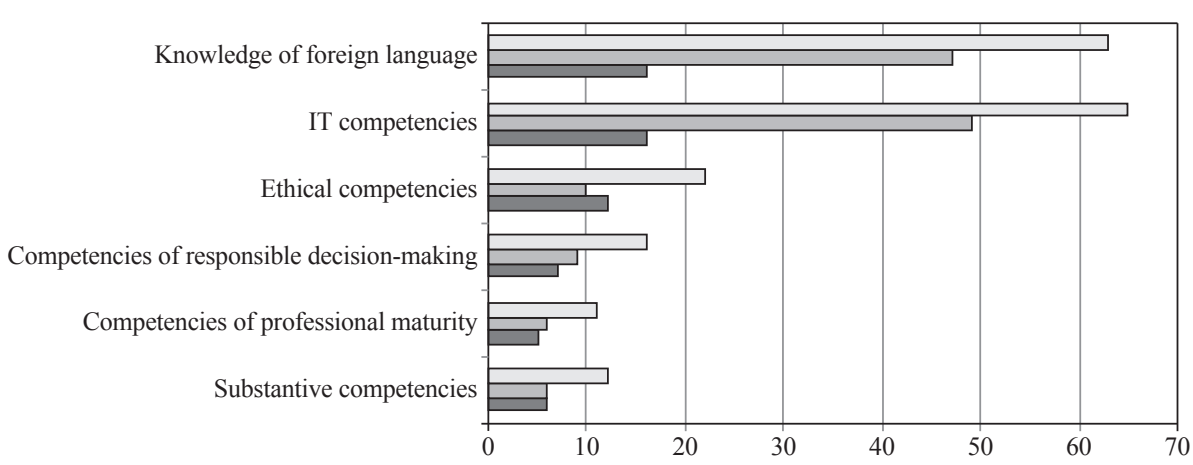

$\square$ Sum of all experts' indications $\square$ Number of managers' indications

Number of professors' indications

Fig. 2. Expert Opinion on the Validity of General Competencies for Effective Operation in a Changing Environment

Source: the author's own elaboration.

According to the experts, leadership competencies included negotiating competencies, coaching competencies, motivating subordinates, communicative competencies and teamwork competencies as extremely valuable (Figure 3).

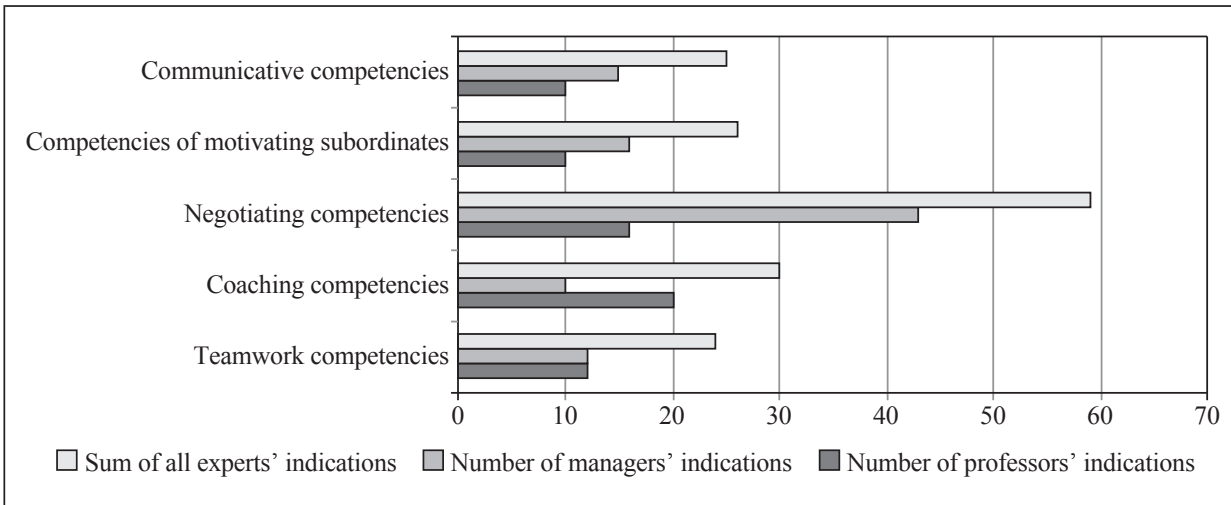

Fig. 3. Expert Opinion on Validity of Leadership Competencies for Effective Operation in a Changing Environment

Source: the author's own elaboration.

Business competencies included project management competencies, innovative competencies and the ability to introduce changes of particular importance for the effective operation in a changing environment (Figure 4). 


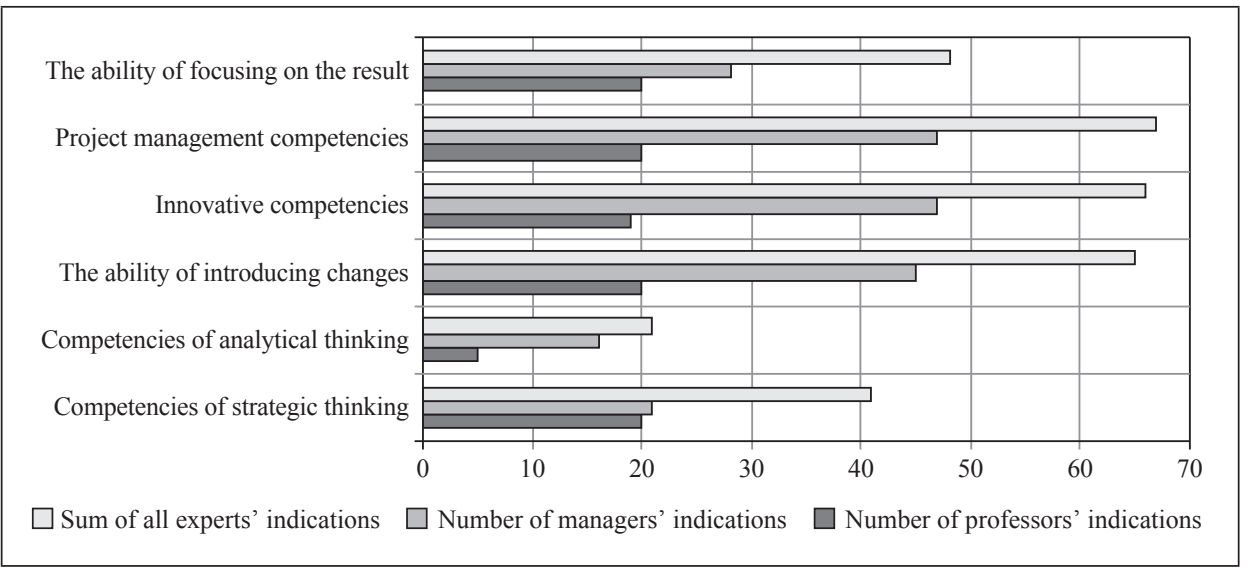

Fig. 4. Expert Opinion on the Validity of Business Competencies for Effective Operation in a Changing Environment

Source: the author's own elaboration.

Among the necessary specialised competencies, experts listed knowledge and the ability to use modern methods whose application requires sophisticated IT and statistical tools specific to the management of a particular functional area within the organisation: marketing, production, human resources and finance.

\section{Conclusion}

The correlation of success in an enterprise with managerial competencies requires a competence model to be chosen to provide the basis for various personnel activities: recruitment, assessment, remuneration and the development of managerial staff (Whiddett \& Hollyforde 2003). Such a model indicates those competencies that are particularly valuable for developing and improving sources of competitive advantage for an enterprise. However, the basic aim of creating a competency model is to compare and assess real managerial competencies with master structures of competencies describing demands at work in an actual enterprise. The point of this comparison is to identify competent and incompetent managers.

Competent managers assure success in an enterprise by creating and consolidating customer values, refunding invested capital, and expanding long-term value for shareholders. Proper managerial competencies are a condition for good management: taking proper decisions and committed leadership to assure that those decisions translate into concrete activities, while maintaining strategic 
perspective and reconciling the imperative of efficiency with ethical conduct and social responsibility (Thomas, Miles \& Fisk 2009, p. 13).

Managerial incompetence, on the other hand, results from a lack of knowledge and experience in enterprise management, leading to ineffectiveness that ultimately results in a failure to make the right decisions in a timely manner and missed investment opportunities. Incompetence also causes managers to fear losing their post and implementing some measures, e.g. avoiding difficulties or experiments with novel approaches, and adopting new ideas in order to minimise the negative (or difficult to forecast) results of decisions taken.

This paper has identified competencies that are important for managers to manage effectively at all levels of management, from the highest to the lowest. The highest level of management calls for business competencies, while for middle management, leadership competencies are key. Low-level managers most need specialised competencies.

According to the model of a modern manager, the manager has a thorough education and is primarily an effective entrepreneur, an outstanding leader and a reliable specialist able to operate in a changing business environment, with the ability to use specialised knowledge.

In the future, the competence models presented in this paper can be used to identify competence gaps of management staff. This is important because the appearance of such gaps can make it difficult if not impossible for the enterprise to function, let alone develop, innovate, and improve or constantly guarantee its competitive position.

\section{Bibliography}

Bamel U. K., Rangnekar S., Stokes P., Rastogi R. (2015), Managerial Effectiveness - an Indian Experience, "Journal of Management Development", vol. 34, no 2, https://doi. org/10.1108/JMD-10-2012-0129.

Dubois D. D., Rothwell W. J. (2008), Zarządzanie zasobami ludzkimi oparte na kompetencjach, Helion, Gliwice.

Filipowicz G. (2004), Zarzadzanie kompetencjami zawodowymi, PWE, Warszawa.

Gierszewska G., Romanowska M. (1999), Analiza strategiczna przedsiębiorstwa, PWE, Warszawa.

Huping S., Wenxuan Y. (2013), Assessing Chinese Managerial Competencies from Different Perspectives, "Social Behavior \& Personality: an International Journal", vol. 41, no 9.

Jena S., Sahoo C. K. (2014), Improving Managerial Performance: A Study on Entrepreneurial and Leadership Competencies, "Industrial and Commercial Training", vol. 46, no 3, https://doi.org/10.1108/JCT-10-2013-0066.

Katz R. L. (1974), Skills of an Effective Administrator, "Harvard Business Review", vol. 52, no 5 . 
Lakshminarayanan S., Pai Y., Ramaprasad B. S. (2016), Competency Need Assessment: A Gap Analytic Approach, "Industrial \& Commercial Training", vol. 48, no 8.

Listwan T. (1993), Ksztattowanie kadry menedżerskiej firmy, Mimex, Wrocław.

Masłyk-Musiał E. (2005), Kompetencje współczesnego menedżera (in:) Zarzadzanie kompetencjami w organizacji, ed. E. Masłyk-Musiał, Wyższa Szkoła Menedżerska, Warszawa.

Oleksyn T. (2006), Zarzadzanie kompetencjami. Teoria i praktyka, Oficyna Ekonomiczna, Kraków.

Peterson T. O., Van Fleet D. D. (2004), The Ongoing Legacy of R. L. Katz. An Updated Typology of Management Skills, "Management Decision", vol. 42, no 10, https://doi. org/10.1108/00251740410568980.

Pocztowski A. (2003), Zarządzanie zasobami ludzkimi. Strategie - procesy-metody, PWE, Warszawa.

Pocztowski A., Miś A. (2000), Modelowanie kompetencji kierowniczych $w$ aspekcie kapitału ludzkiego w organizacji (in:) Kształtowanie kapitału ludzkiego firmy, ed. B. Kożuch, Wydawnictwo Uniwersytetu w Białymstoku, Białystok.

Rakowska A. (2005), Kompetencje współczesnego menedżera (in:) Zarządzanie kompetencjami w organizacji, ed. E. Masłyk-Musiał, Wyższa Szkoła Menedżerska, Warszawa.

Stabryła A. (2011), Universal Research Approaches in Designing Development Project, Zeszyty Naukowe Małopolskiej Wyższej Szkoły Ekonomicznej w Tarnowie, Tarnów, vol. 19, no 2.

Thomas M., Miles G., Fisk P. (2009), Kompetentny CEO, Wydawnictwo Oficyna a Wolters Kluwer business, Kraków.

Tyrańska M. (2015), Koncepcja systemu oceny kompetencji kadry menedżerskiej w przedsiębiorstwie, Wydawnictwo Uniwersytetu Ekonomicznego w Krakowie, Kraków.

Walkowiak R. (2004), Model kompetencji menedżerów organizacji samorzadowych, Wydawnictwo Uniwersytetu Warmińsko-Mazurskiego, Olsztyn.

Whiddett P., Hollyforde P. (2003), Modele kompetencyjne w zarządzaniu zasobami ludzkimi, Oficyna Ekonomiczna, Kraków.

\section{Kompetencje kadry menedżerskiej na różnych szczeblach zarządzania (Streszczenie)}

Współcześnie kompetencje menedżerskie są przedmiotem zainteresowania badaczy na całym świecie. Znajduje to odzwierciedlenie w dużej liczbie publikacji na ten temat. Badane są kompetencje menedżerów zarządzających przedsiębiorstwami i zarządzających organizacjami publicznymi. To duże zainteresowanie kompetencjami menedżerskimi wynika z faktu, że mają one wpływ na efektywność zarządzania organizacjami.

Podstawowym narzędziem zarządzania kompetencjami, które umożliwia identyfikację niezbędnych dla danego przedsiębiorstwa kompetencji menedżerskich, ich zapewnienie, ocenianie i doskonalenie, jest lista kompetencji kadry menedżerskiej, która może służyć do identyfikacji luk kompetencyjnych kadry menedżerskiej.

Celem artykułu jest przedstawienie, na podstawie przeprowadzonej analizy literatury, listy kompetencji kadry menedżerskiej, które zdaniem autorki są niezbędne dla menedżerów zarządzających współczesnymi przedsiębiorstwami. Ponadto dla uszcze- 
gółowienia prezentowanych rozważań ukazano, opierając się na wynikach przeprowadzonych badań, kompetencje istotne dla skutecznego działania menedżerów na różnych poziomach zarządzania: najwyższym, średnim i najniższym. Badania przeprowadzono z zastosowaniem metody delfickiej. W badaniach uczestniczyło 100 ekspertów, w tym 42 profesorów z zakresu zarządzania oraz 58 menedżerów zatrudnionych na różnych poziomach zarządzania w przedsiębiorstwach zatrudniających co najmniej 50 pracowników. Wyniki przeprowadzonych badań zostały porównane z modelem umiejętności menedżerskich R.L. Katza.

Słowa klucze: kompetencje menedżerskie, metoda delficka, istotność kompetencji menedżerskich, model umiejętności menedżerskich R.L. Katza. 